This article was downloaded by: [130.132.123.28]

On: 04 J anuary 2015, At: 08: 28

Publisher: Routledge

Informa Ltd Registered in England and Wales Registered Number: 1072954

Registered office: Mortimer House, 37-41 Mortimer Street, London W1T

3J H, UK

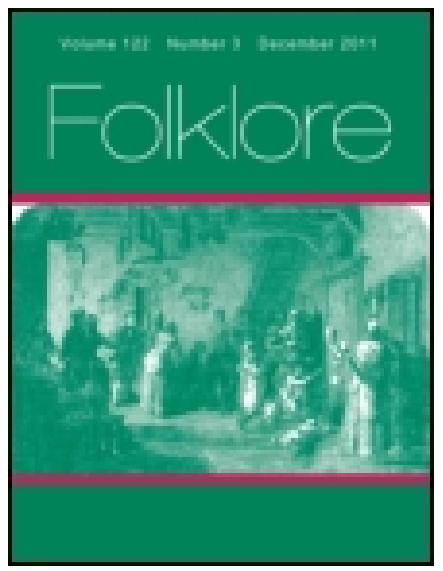

\title{
Folklore
}

Publication details, including instructions for authors and subscription information:

http:// www.tandfonline.com/loi/ rfol20

\section{Folk-Lore Miscellanea}

W. H. D. Rouse, H. G. M. Murray-Aynsley , T. W. E. Higgens \& Percy Manning

Published online: 14 Feb 2012.

To cite this article: W. H. D. Rouse , H. G. M. Murray-Aynsley, T. W. E. Higgens \& Percy Manning (1893) Folk-Lore Miscellanea, Folklore, 4:3, 396-404, DOI: 10. 1080/ 0015587X. 1893.9720176

To link to this article: http:/ / dx.doi. org/ 10.1080/ 0015587X. 1893.9720176

\section{PLEASE SCROLL DOWN FOR ARTICLE}

Taylor \& Francis makes every effort to ensure the accuracy of all the information (the "Content") contained in the publications on our platform. However, Taylor \& Francis, our agents, and our licensors make no representations or warranties whatsoever as to the accuracy, completeness, or suitability for any purpose of the Content. Any opinions and views expressed in this publication are the opinions and views of the authors, and are not the views of or endorsed by Taylor \& Francis. The accuracy of the Content should not be relied upon and should be independently verified with primary sources of information. Taylor and Francis shall not be liable for any losses, actions, claims, proceedings, demands, costs, expenses, damages, and other liabilities whatsoever or howsoever caused arising directly or indirectly in connection with, in relation to or arising out of the use of the Content.

This article may be used for research, teaching, and private study purposes. Any substantial or systematic reproduction, redistribution, reselling, loan, sub-licensing, systematic supply, or distribution in any form to anyone is 
expressly forbidden. Terms $\&$ Conditions of access and use can be found at http://www.tandfonline.com/page/terms-and-conditions 


\section{FOLK-LORE MISCELLANEA.}

Folk-lore Items from North Indian Notes and Queries, edited by William Crooke, B.A. (Constable and Co.)

(The references are by volume and paragraph. The current volume is II, and these notes begin with January of the present year.)

Popular Religion.-6r. N.W. Provinces. A long song, text and translation. Sāhū Sãlār, in digging the foundations of a watch-house, unearths a demon. [This throws light on the human sacrifice so often used in beginning a building, which must be propitiatory.]

6r3. Customs of the Sultani Sikhs. (Those who cannot go on the great pilgrimage of these people sleep at home at least one night on the ground as a substitute.)

717. Hindu annual festival of snake-worship or appeasing, and fast on Feb. 16th.

726. Instances of Mother Satti, mothers dying by satti with their sons, not their husbands (Rajputana).

729. Yearly ceremony of snake-worship, and charm against snakebite (Agarwāla Banyas). [The Atharva Veda has numbers of charms against snake-bites.]

Sociology.-6r 5, 627, 680. Hoshiarpur. Marriage regulations.

616. Ludhiana. Birth ceremonies. (Midwife ties iron ring over the door.)

623. Ludhiana. Jat betrothal ceremonies. (Brides are often purchased.)

624. Marriage ceremonies among the Jats of Ludhiana. (Walking round the fire.)

626. Muhammadan marriage customs: Jalandhar.

681. " " " Ludhiana.

687. " " " " Agarwālas.

695. " " " (polyandry) Dehra Dun.

708. " " " the Khurwars.

682. Land tenure.

691. Manorial dues: Garhwal.

693, 694. Death ceremonies.

731. Couvade in India. 
732. Birth, betrothal, and marriage among the Agarwāla Banyas. (The clothes of the bride and bridegroon are tied in a knot.)

733. Tattooing of women (N.W. Prov.). Conciliates the mysterious opponents who beset the path traversed after death. Imitations of ornaments, since no other ornament can be taken to the next world. Remedy for disease and barrenness.

738. Procedure of sorcerers to cure disease (Kumaon). The usual ecstasies, and instances of second-sight more or less correct. The writer vouches for one of them; he tested the man himself.

Folk-lore.-633. The Princess who got the gift of patience. The tale contains incidents like that of Psyche. The fairy prince visits his bride only at night, when she turns a magic fan upside down. Envious sisters grind glass fine, and lay it under the sheet. The prince falls into horrible pain, and the princess finds out what is the matter, and how to cure it, by hearing birds talk.

634. Superstitions of husbandry.

643. Another version of the Fairy Gift legend. A saint gives a herdsman a handful of barley, which turns into gold at home.

699. Tale of an ass which dropped money.

703. "Scapegoat" animal carries off disease.

704. The Magic Ring of Lord Solomon. Contains the following incidents : Wishing Ring (cp. Lang's Blue Fairy Tale Book, No. 1); prince leaves a cup of milk with his mother, saying, "As long as this milk does not turn sour, know that I am alive." The princess throws three hairs into the river, and a king who finds them falls in love with her. A witch gets the ring, and spirits the princess away. A dog and cat get the ring back by aid of a mouse. [Almost the same story from South India in Clouston's Popular Tales and Fictions i, 337.]

739. The pranks of Hop-o'-my-Thumb (Mirzapur).

740. Shekh Chilli and the Thieves : "four corners and one above."

742. A monster who boiled boys in oil. The hero throws him in, boils him, and sprinkles the oil on the bones which lie about. The boys previously boiled come to life again (Mirzapur).

743. The Man who Fought with God. Three questions asked on the way by people whom he came across, which he gets answered (Mirzapur).

744. Princess Pomegranate. Prince plucks a pomegranate off a tree, but is told to take no more. He at first does so, and is killed; then he only took one, and it burst, and a princess came out. Envious woman, who kills the princess, and takes her place; princess returns in form of a flower, which is pricked to pieces, from which a pomegranate-tree grew, and bore one fruit, from which the princess came vol. IV. 
out again. Envious woman had her killed, and ate her liver. At length she is restored, and marries her prince (Mirzapur).

745. Tasks of the Witch Queen. The witch maligns a young queen, and, after many misfortunes have befallen the young queen, her son learns that the witch's life rests in a parrot, which he kills.

Ethnology.-65I. (Goat-butchers will not kill cows, and vice versa.) 654. Montgomery-Ioya Tribe. "Iot means a wife, and it would seem as if the tribe got its name from no one knowing who their male ancestor was."

648, 705. Physical differences between Europeans and Asiatics worked out in great detail. The writer holds that "in using force, even to the most trifling matter, the European appears to depend chiefly on his extensoral development, and the Asiatic on his flexoral.

W. H. D. Rouse.

The Sin-Eater.--In his work on Turkestân, ${ }^{1}$ Dr. Schuyler speaks of a custom existing in that country which is worth noting in connection with Mr. Sidney Hartland's paper on this subject in the June number of FOLK-LORE, 1892. "Life in Ach Kûrgân", Dr. S. says, "was rather dull, amusement there was none, all games being strictly forbidden. Such things as jugglery, dancing, and comic performances are, I am told, forbidden in the Kanate, the licentious Khan having seen the error of his ways, and having put on, for his people at least, the semblance of virtue. Of praying there was very little ; occasionally in the afternoon at sunset some few pious individuals would spread out a rug and make their supplications to Allah. One poor old man, however, I noticed, who seemed constantly engaged in prayer. On calling attention to him, I was told that he was an iskachi, a person who makes his living by taking upon himself the sins of the dead, and thenceforward devoting his life to prayer for their souls. He corresponds to the sin-eater of the Welsh border."

In Kashmir, on the borders of Central Asia, where the present writer now is, it is the living, apparently, who need a sin-eater.

We have just passed through a terrible visitation of cholera; when the outbreak was at its worst, the deaths in the native city rose to nearly three hundred daily. An order then came from the Maharaja (who was at Jamu, his second capital') that a couple or more bulls

Vol. ii, p. 28.

2 The chief town of a fief belonging to the Maharaja of Kashmir's progenitors for two or more generations before Kashmir was given over to that family. 
were to be bought, and driven for some hours round and about the streets and the lanes of the city, and then turned out loose to wander at will, in order to remove the pestilence.

It was accordingly done, and the effect this would seem to have had on the minds of the people was something marvellous; the seizures diminished, and the death-rate suddenly declined in a most marked manner. It would appear that the Kashmiris believed either that these animals bore away the disease, or the sins and shortcomings which had brought this scourge upon them.

At Jamu itself, some years ago, the writer saw numerous ownerless cattle wandering about the native city and its environs, and was then told that these were animals which, by a particular ceremony, had had the sins of certain persons laid upon them; they looked sleek and wellfed, living most probably upon the charity of the general public.

The notion regarding the sin-eater in Southern Italy becomes even more directly personal, as the following anecdote serves to show. The writer had it from a Roman lady who had then resided some years in Naples, she knew one of the parties concerned, and spoke of it as a singular piece of superstition. A family of her acquaintance had settled themselves down in an apartment in that city; not long afterwards another flat in the same house was taken by a lady whom the first-comers believed possessed the $M a l$ Occhio=the Evil Eye. They were in despair, and, in order to avert any bad consequences which might result to themselves, they caused a bull to be brought to the house, and had it driven through the entrance archway, and led round and round the courtyard for some hours. There seems a remarkable connection between the sin-eater of Central Asia and of the Welsh border, the bull of Kashmir, and the Neapolitan custom.

Srinagar, Kashmir, July 28, 1892. H. G. M. MURRAY-AyNSLEY.

John Aller. - The following story was told me in the summer of 1885 by a farmer at Aller in Somersetshire (Mr. Dudridge), to account for the origin of the name of the village.

He also informed me that there was a monument to Aller in the church, but this was incorrect.

The village of Aller is distant about two miles from Curry Rivell, both villages are on the sides of hills, and the intervening country is flat and marshy.

The spot pointed out to me as the site of the encounter is a bare patch of sand, very noticeable on the green hill-side as you approach by the Langport road.

The rector of Aller had never heard the story. 
"Many years ago a fiery flying dragon lived at Curry Rivell. At certain times it used to fly across the marsh to Aller and destroy the crops and all it came near, with its fiery breath. This continued for a long time. At last one John Aller, a brave and valiant man, who lived at Aller, vowed that he would kill it. He laid in wait, and when next the dragon flew across to Aller hill he attacked it, and, after a fierce struggle, slew it, and cut off its head. Then its fiery blood ran out, and scorched up all the grass around, and from that day to this grass has never grown on the spot. John Aller was so burnt by the dragon's breath that he died almost at the same moment as the dragon. The people took up his body, buried it in the church, and called the village after him."

\section{T. W. E. Higgens.}

The Flitting Gnomes.-It may be assumed that folk-lorists are acquainted with Crofton Cookes's delightful Fairy Legends and Traditions of the South of Ireland, and will remember, in the section devoted to "The Clericaune" (vol. ii, p. 163), how an old Quaker gentleman, haunted by one of these fairies, desired to get rid of him, and for that purpose took another house, and had all his furniture packed on carts, when, as the last casks were being put on, the Clericaune was seen to jump on to the car, and into the bunghole of an empty cask, and cry : "Here, master, here we all go together." Whereupon the Quaker said: "In that case let the cars be unpacked; we are just as well where we are!" Another similar instance of the Danish Nis is also adduced. In The Land of Manfred, by Miss Janet Ross, a book rich in folk-lore, a like being with the same story is described as popularly believed in in the extreme South of Italy. When near Tasanto, Miss Ross relates (pp. 127-8), "I observed that some of the flock an old shepherd was guarding looked tired, and hung their heads wearily. I asked whether they were ill, and he answered : 'No, but I must get rid of them, because the Laùro has taken an antipathy to them.' On further inquiry he told me that the Laùro was a little man, only thirty centimetres high, always dressed in velvet, and wearing a Calabreze hat with a feather stuck into it. The Laùro is most capricious : to some who ask him for money he gives a sackful of broken potsherds; to others who ask for sand he give old coins. He took a particular dislike to a cousin of the old shepherd, sitting on her chest at night and giving her terrible dreams. At last she was so worried by the Lauro that she determined to leave her house. All the household goods and chattels were on the cart; nothing was left but an old broom, and when the goodwife went to fetch it the Laùro suddenly appeared, saying: " I'll take that; let us be off to the new house.' His antipathies or likings are unaccount- 
able ; he will steal corn from one horse or mule to give it to another ; twist up their manes and tails in a fantastic way, or shave them in queer patterns. The Laùro could not allow the sheep $I$ had asked about to rest at night, and any animal he hated had to be sold." Thus a being with the same attributes and story attached is known in Denmark, Ireland, and the far South of Italy.

The Monaciello of Naples.-Belief in the Monaciello, or Little Monk, still prevails all around the Bay of Naples; he is described as broad, sturdy, and dwarfish ; wearing a monk's dress, but a broad: brimmed hat. $\mathrm{He}$ is mischievous and tricky, sometimes spiteful; often alluded to in the Pentamerone. In one of the tales, "Vardiello," a house is mentioned that had been deserted on account of the annoyances occasioned by the Monaciello. Except that he is never associated with the Will-o'-the-Wisp he would seem to be somewhat akin to the English Friar Rush. It is, however, in Sorrento that the Monacielli appear to have their headquarters. Visitors to Sorrento will remember the extraordinarily deep, narrow ravines which traverse the town; these are at the present day believed to be peopled by Monacielli, who elsewhere appear to be of solitary habits. When at Sorrento, four years ago, I had a fancy of trying to get to the bottom of one of those very deep precipitous clefts. No one, however, would go with me, and I was strongly dissuaded from the attempt, as there was no telling what might befall an intruder in those haunted depths. Beside the Monaciello, one hears stories of a sort of house-spirit known as the Bella 'Mbriana, that tenants many of the houses in St. Agata, Massa, and other villages near Sorrento. It is not easy to get any distinct idea of this being. Unlike house-spirits in general, she is female and never seen; but her presence in the house is always acknowledged and spoken of with great deference, and the epithet "bella" is no doubt placatory, like the "good people" applied to the fairies; for, though generally beneficent, she can be malicious, and, while exacting the greatest courtesy, dislikes being spoken of directly. The village people may have clearer ideas of her, but it is difficult for strangers to get at them.

Dwarfs in the East.-Mr. Keightley, in his Fairy Mythology, expressed his conviction that the ancients knew of no diminutive beings like British Fairies or Northern Duergar. Neither does popular belief know of any such throughout the East. In India rings are not uncommonly seen in the grass after rain, but no popular superstition is connected with them ; no beings, like elves or fairies, find place in village traditions or belief. The Hindu mind inclines more to the idea of hideous malevolent demons, especially female. A belief in dwarfs, 
not unlike the Duergar, is, however, much more familiar, for dwarfs hoid a distinct place in Hindu mythology ; they appear sculptured on all temples. Siva is accompanied by a bodyguard of dwarfs, one of whom, the three-legged Bhringi, dances nimbly. But coming nearer to Northern legend, the cromlechs and kistvaens which abound over Southern India are believed to have been built by a dwarf race, a cubit high, who could nevertheless move and handle the huge stones easily. The villagers call them Pandayar. In the Chingalpat district, near Madras, there is a large mound said to be inhabited by a bearded race of Pândayar, three feet high, whose king lives in the top of the mound. This nearly approaches the traditions of hill-dwarfs in Norway ; but no skill or habit of working in metal is associated with them. The late Mr. Fergusson (Tree and Serpent Worship, p. 79) held that "all the Fairy Mythology of East and West belongs to the Turanian races"; and the late learned Bishop Caldwell, who laboured for a lifetime amongst the people in Southern India, suggested that the Tamil word pey-demon or goblin-may be the origin of the word "fairy", but their attributes respectively, as popularly understood, seem too widely diverse. It may be noted, however, that in Scandinavian mythology we hear of the dark Alfar, or malignant elves. Brotier thinks the word "Alf" may be derived from the Teutonic deity Alcis, mentioned by Tacitus (Germania, 43), identified by him with Castor and Pollux in their jack-o'-lantern appearances.

Dwarfs in the West. - The Rev. Baring Gould, in his pleasant and instructive volume, In Troubadour Land, published in the present year, relates a curious experience of his boyish days. While sitting on the box of his father's carriage crossing the Cran, a wide, desolate, stony tract in Provence, he suddenly saw a number of little figures of men with peaked caps, running about the horses and making attempts to scramble up them. For some time he continued to see these dwarfs running among the pebbles of the Cran, jumping over tufts of grass, or careering along the road by the carriage, making faces at him; but gradually their number decreased, and he failed to see any more (pp. 65-6). They were visible only to him, and on saying something about it to his father, he was sent inside the carriage, on the supposition that the sun was too hot for his head. Mr. Gould adds an anecdote of his wife, "who never deviated from the truth in her life, and who walking one day, when a girl of thirteen, beside a quickset hedge, her brother on the other side looking for birds' nests, all at once saw a little man dressed entirely in green, with jacket and high peaked hat, seated in the hedge staring at her. She was paralysed with terror for a moment, then called her brother to come round and see the little green man. When he arrived the dwarf had 
disappeared." Mr. Gould supposes this vision, too, would be ascribed to a too hot sun on the head, but is evidently dissatisfied with that explanation, and asks why a hot sun should call up visions of dwarfs and fairies. It is the fashion now to make light of the tone and sensible avouch of our own eyes, but, railways notwithstanding, fairies may still exist for those who have the gift of seeing them. Mrs. Baring Gould's experience, however, recalls a story current on the eastern border of the Dartmoor, where still stands a farm-house, of which it is told that some years ago the farmer who lived there was coming home from market rather late, and saw in the hedge, not far from his house, a tiny little woman sitting dressed all in green. She was a pixy, and the farmer, probably bold after sundry drops at the market-town, picked her up and carried her home. There he told his wife, who had gone to bed, what he had found, and asked what he should do with her. The wife answered, sleepily: "Tie her to the bed-post with your garter." The farmer did so, and went off to sleep. In the morning he looked at once at the bed-post, and there was his garter as he had tied it the evening before, but no little green lady in it, only a long green leek! Disgusted at this, he seized the leek, and opening the door, threw it out into the yard, when, as it left his hand, it changed back into the woman in green, and he saw himself suddenly surrounded by a swarm of tiny beings, mounted on little horses, who presently vanished, clapping their hands, and crying: "We have got her again! we have got her again !"

M. L. C.

May-Day at Watford, Herts.-On May-Day, in this parish, groups of children, almost entirely girls, go about the streets from door to door, and sing the accompanying verses. They are dressed in white for preference, and decorate themselves with gay ribbons and sashes of various colours; I cannot find that any particular colours are prescribed by tradition. Two of the girls carry between them on a stick what they call "the garland", which, in its simplest form, is made of two circular hoops, intersecting each other at right angles ; a more elaborate form has, in addition, smaller semicircles inserted in the four angles formed by the meeting of the hoops at the top of "the garland". These hoops are covered with any wild-flowers in season, and are further ornamented with ribbons. The "garland" in shape reminds me of the "Christmas" which used to form the centre of the Christmas decorations in Yorkshire some few years ago, except that the latter had a bunch of mistletoe inside the hoops.

One of the children generally carries a purse or small bag to hold the coppers which may be collected. The group, of which I have a photograph, was one taken quite at hap-hazard, as it passed the 
photographer's door. In this a boy with a bunch of flowers on a stick accompanies them, but this is not very usual.

Verses sung by Children at Watford, Herts, on May-Day.

1. Here begins the merry month of May,

The bright time of the year,

When Christ our Saviour died for us,

Who loved us so dear.

2. So dear, so dear, Christ loved us,

And all our sins to save ;

We'd better leave off our wickedness,

And turn to the Lord again.

3. I have been travelling all this night,

And best part of this day,

And now I have returned again,

I 've brought you a branch of May;

4. A branch of May I have brought you, And at your door I stand,

It is but a bud, but it's well spreaded out, By the work of our Lord's hand.

5. A garland, a garland, a very pretty garland, As ever you wish to see,

'Tis fit for the Queen Victoria, So please remember me.

6. I have a little purse within my pocket, Dressed up in silk and string,

And all I want is a little piece of money, So please to put within.

7. My song is done-I must be gone,

No longer can I stay;

God bless you all, both great and small;

I wish you a merry month of May.

\section{Variants.}

3. We have been walking all the night, And the best part of this day;

And now returning back again,

We bring you a branch of May.

4. A branch of May we have brought you,

And at your door it stands;

It is but a sprout, but it 's well budded out, In the shape of our Lord's hands. 